\title{
Geological Uncertainty and Poetic Creativity: The Material Agency of Findlinge for Droste-Hülshoff and Goethe
}

\section{Jillian DeMair}

Findlinge - literally "foundlings," in English referred to as erratics, drift blocks or wandered stones - are rocks that are found a great distance from their place of origin and often appear uncannily out of place in the landscape. Scientists today know that the non-native rocks, fossils, and other sediment found in the northern part of Central Europe were transported by glaciers during past ice ages from Scandinavia, the Baltic Sea, and the Baltic coast and then left behind when the glaciers receded ("Zeugen aus dem Norden"). Findlinge in southern Germany, Austria, and Switzerland generally stem from glaciers that moved northwards from the Alps (Hurni 57-58). Yet at the time when these rocks were being depicted in literary works by Johann Wolfgang von Goethe and Annette von Droste-Hülshoff, the evidence for this scientific explanation was not yet fully in place. Various hypotheses, including Goethe's favoured theory of Neptunism and Georges Cuvier's catastrophism, attributed the movement of rocks to massive floodwaters, but the lack of a proven explanation gave Findlinge a mysterious quality. Their anthropomorphized name contributes to the sense that they are disoriented voyagers or displaced orphans. In this way, they seem to have their own agency, and indeed, these rocks hold secrets from ancient history, including information about the existence of glaciers and, through the fossilized remains they contain, living creatures. For Droste-Hülshoff and Goethe, these rocks came to stand in for the mobility, agency, and unpredictability of nonhuman matter more generally and as such are endowed with a creative force. These two authors share a unique perspective that removes the poetic subject from the centre point of literary portrayals, and instead recognizes the agency of nonhuman matter and the ways in which humans are entangled as one entity among many in natural processes.

The depiction of a poetic subject that is contingent on the upheavals of the earth's geological processes is aligned with Sabine Wilke's assessment of the aesthetic system developed by Goethe and Alex- 
ander von Humboldt, which moved away from the depiction of the earth at the mercy of heroic male discoverers and toward a presentation of ecology that "emphasizes the smallness of the figures vis-àvis the vastness of nature and it turns them into insignificant elements, almost afterthoughts" (273). Beyond the visual aspect of Goethe's and Humboldt's artistic renderings, the same sentiment can be seen in Goethe's literary reflections on the earth's geological features. Droste-Hülshoff, too, moves away from Romantic self-centred subjectivity in her work and instead portrays a subject shaped by its surroundings. Martha B. Helfer calls this "alterpoeisis," meaning "the active and intentional decentring of the subject, the selfreflexive process through which the self stages itself dynamically as object, as an object among objects" (284). The poetic subject in Droste-Hülshoff's 1842 poem "Die Mergelgrube" ("The Marl Pit") climbs down into the earth and imagines experiencing its history through the different objects found there, including Findlinge and fossils. Helfer's assessment that the object-driven subjectivity in Droste-Hülshoff's works was inaugurated by Goethe lays the groundwork for the present essay's alignment of these two writers in their treatment of geological phenomena as scientific mysteries rather than objects of nature poetry. Their respective approaches to natural history go beyond the literary historical trend that Josefine Nettesheim observes in Droste-Hülshoff, Freiligrath, and Lenau, noting the shift in focus from the classical objects of nature poetry (the rose, the idyllic landscape) to the mundane, minute, demonic, or scientific as a source of inspiration (20-25). While this trend explains some aspects of their work, Findlinge appear in Droste-Hülshoff's and Goethe's works as more than a unique or mysterious source of inspiration. They are included for their role in scientific inquiry and recognized as objects that bear their own creative potential. ${ }^{1}$ Recent

\footnotetext{
${ }^{1}$ Goethe, however, does not use the term Findling when discussing them. Jason Groves traces Goethe's use of terminology for these erratic rocks, discussing his avoidance of any term that confronts the uncertain, unpredictable aspect of these stones, preferring instead phrases such as "umherliegende Granitblöcke" ("lying-around granite blocks"); "Granit-Geschiebe" ("granite debris"); "Gebirges-Trümmer" ("mountain rubble"); and "ungeheure Felsblöcke" ("tremendous boulders") (32).
} 
ecocritical perspectives, as Hubert Zapf points out, have helped to loosen the concept of creativity from its strong ties to human culture, instead recognizing it as a property of material nature more generally (51). Although the present analysis inevitably approaches "creative matter" through human creativity, it aims to recognize the particular ways in which Droste-Hülshoff and Goethe depict the creative processes in nature, which - like human creativity - are but one component intertwined with broader natural structures.

The Findling is just one example of how literary creativity has been derived from natural objects, but it is unique in that it represents the intersection of literary and scientific pursuits for these two authors, who are alone in exploring the Findling in literary works around this time. ${ }^{2}$ The fascination with the aesthetic of stone more generally and the interactions between the organic and inorganic had already been a major source of poetic inspiration around 1800, as seen, for example, in the many variations on E.T. A. Hoffmann's Mines of Falun tale (Groves 9-10). Certainly, Droste-Hülshoff and Goethe were not the only influential writers during this time period for whom the study of nature and poetic production were closely intertwined. To the contrary, it was a frequent pursuit in the Enlightenment and Romanticism. Wilke points out that in the eighteenth century, "no scientific insight into the interplay of the forces of nature can be envisioned without an aesthetic" (262). However, by 1830 or 1840 the border between science and aesthetics had become far less permeable than it had been up until 1800 (Brandt 34). The eighteenth-century idea of the Naturforscher ("natural philosopher"), someone who was invested in a broad range of intellectual and aes-

${ }^{2}$ To the best of my knowledge, these are the only two authors who integrate the Findling into poetic works at this time. Although Paul Celan does so much later, the historical context of his post-Holocaust works makes his use of this image too different to be included in the present analysis. Erika Schellenberger-Diederich provides a thorough examination of Celan's modern geo-poetics (296-318). Groves includes Adalbert Stifter in his study of textual practices that invoke geological instabilities, especially erratics. However, Stifter is writing somewhat later than the two authors in question here, and the stones he includes in his works are not explicitly portrayed as Findlinge, as Groves acknowledges with regard to the story Granite (101). 
thetic pursuits and belonged to a "loose, decentralized community," shifted drastically over the course of the nineteenth century, when Naturwissenschaft ("natural science") acquired a more specific meaning and experts organized themselves into scientific societies (Phillips 28-29). ${ }^{3}$ Of course these developments affected DrosteHülshoff and Goethe differently; as before, gender was a boundary marker and the "networks of natural knowledge" were generally composed exclusively of men (Phillips 54). Some male writers welcomed women as members of the educated, reading public, and yet this category was often distinguished from the "learned" public (54). While Droste-Hülshoff's access to these communities may have been more restricted than Goethe's, she did participate in intellectual inquiry and exchange through her correspondence, a well-appointed family library, and her own collection of minerals, stones, and fossils (Pittrof 161-62). Findlinge are closely linked with fossils insofar as both contain snapshot of natural history in their very substance, distanced either in time, space, or both, from their origins. What is more, the many Findlinge strewn across the German countryside that had originated in Scandinavia often contained fossilized remains that furthered paleontological research (Schaffer 321).

Although "creativity as a general feature of material nature" has only been recently acknowledged by ecocritics (Zapf 52), DrosteHülshoff and Goethe already recognized the ways in which rocks can be read for evidence of the metamorphoses of natural history, and, if they contain fossils, of the cycle of exchange between living creatures and their environments. These authors find creative potential in rocks that live two lives: they appear stubbornly immobile, are often immovable, and yet have long existed as extraordinary voyagers that demonstrate the instability of the surface of the earth. As Jeffrey Jerome Cohen describes in his foreword to the 2014 volume Material Ecocriticism, stillness is relative: "a rock within its properly geologic

${ }^{3}$ I translate Naturforscher as "natural philosopher" following Denise Phillips's illustration of the meanings these terms had acquired in Germany and Britain in the nineteenth century. She ascribes the challenge of translation from the German to the different groups of disciplines represented in the early scientific societies in the respective countries. See Phillips's Acolytes of Nature, p. 5 . 
duration [is] a wayfarer, a holder of stories of mountains that undulate and continents that journey the sea" (Cohen ix). These rocks have borne witness to geological changes over millions, even billions of years of history, while also retaining evidence of those massive shifts in their physical composition. Not surprisingly, cultures have long explored the idea that stories are contained within these dislocated rocks. Droste-Hülshoff and Goethe therefore approach not only the geological history of Findlinge, but also the ways in which they have already participated in the interconnectedness between natural and cultural forces. All of these aspects of Findlinge come together to create a " 'narrativity' of matter," to borrow Iovino and Serpil Oppermann's words, which implies the "shared creativity of human and nonhuman agents." (8) In their literary works, Droste-Hülshoff and Goethe derive their own creativity from potentially alienating encounters between human and nonhuman agents while negotiating various explanations of these rocks' material agency.

In Germany today, Findlinge of a certain size are legally protected objects due to their geological and historical importance. They are sometimes recognized individually as natural landmarks such as the Davidstein and Goliathstein (Hannover, Fachbereich Umwelt 3). In other areas, such as Mecklenburg-Vorpommern, all Findlinge that fulfil certain criteria - a minimum volume and length depending on where they are found - are protected (Mecklenburg-Vorpommern, Landesamt für Naturschutz, Umwelt und Geologie). Before they had this status, they were often incorporated into fortresses, city walls, monuments, and burial mounds, and likely had other uses in prehistoric times. In addition to the biblically-inspired names mentioned above, other Findlinge have received proper names that hint at legends about their origins, such as Heidenstein ("heathen stone") or Teufelsbürde ("devil's burden") in Switzerland. The formerly inexplicable presence of Findlinge throughout Europe inspired legends and speculation over the centuries, such as the idea that giants, and later, the devil, had thrown these rocks across the earth or that they were human sinners who had been transformed into stone (BächtoldStäubli 1476-77). Other stories said that the rocks jumped around when they heard certain sounds, such as roosters crowing or bells tolling, or that dwarfs lived inside them (1477). Many of these ex- 
planations have in common the idea of hidden life within non-human matter (Wagner 285).

When Goethe and Droste-Hülshoff were reflecting on Findlinge in the early to mid-1800s, these kinds of explanations were no longer very believable, but evidence for scientific explanations according to which these rocks had been carried along by massive floods, sheets of ice, or other natural catastrophes was equally thin. The impossibility of explaining the Findlinge's origins exhaustively at this particular historical moment fed the literary and scientific imagination. On the scientific side, the apparently inappropriate location of fossils found in Findlinge and other rocks, as well as the fossilized remains of now extinct creatures, created a puzzle that would not be fully solved until theories of evolution and the last ice age were established. Charles Darwin in his 1859 On the Origin of Species by Means of Natural Selection conclusively defended the former. ${ }^{4}$ Darwin's theory no longer required arbitrary forces or divine will to explain extinction and the variation in living organisms, and it entailed recognition that the earth is ancient (Strickberger 16-17). ${ }^{5}$ The latter, glacial theory, was developed in the 1830 s and 40 s by the Swiss naturalist Ignaz Venetz and others, who hypothesized that most of northern Europe, northern Asia, and North America had been covered by sheets of ice during the period that would come to be called the Pleistocene (Allaby 249). From the late 1700s until these theories were established, Cuvier's theory of catastrophism, which held that the earth had been shaped by sudden upheavals such as glaciations and floods, was widely accepted by European biologists. Cuvier

\footnotetext{
${ }^{4}$ Lynn K. Nyhart writes that while Darwin's theory of natural selection was controversial among zoologists in the later nineteenth and early twentieth centuries, evolution was accepted by almost all biologists, and museum and university scientists found it disturbing that it was not being taught in college preparatory schools in Germany by the 1890s and early 1900s (26).

${ }^{5}$ Prior to Darwin, Jean-Baptiste Lamarck and later Charles Lyell had argued for a uniformitarian concept that understood geological changes as the result of gradual change. Change was visible through the same phenomena observable in the world of the present, meaning that the changes to the Earth could be historically understood rather than attributed to supernatural causes (Strickberger 14-17).
} 
himself was not concerned about aligning his theory with the biblical narrative (Robertson 350). But his theory did allow biblical literalists to account for the Great Flood as one of the "discontinuities in the geological record" and to postulate divine intervention to explain the departure of the earth's formation from natural laws (Strickberger 14). This understanding ascribed fossils to a pre-biblical age, and because it rejected the continuity of life forms between major geological upheavals, it was compatible with the idea that all present life forms developed within the time span described in the JudeoChristian Bible (Strickberger 14; Jordan 144-45). ${ }^{6}$ This theory gives humans a separate history, entirely disconnected in natural history from the era attested to by fossilized remains and Findlinge. DrosteHülshoff and Goethe's respective resistance to the centrality of a human figure in their literary works that deal with these geological phenomena indicates a shifting mind-set about natural versus divine agency that resists this anthropocentric view. Droste-Hülshoff draws on Cuvier's catastrophism theory, while Goethe aligns himself with a diluvial theory of Neptunism, an understanding of the earth as gradually shaped by water (Robertson 349-50). However, their works share an openness to a worldview in which geological shifts do not occur by means of divine agency but have other causes that can be studied through science. In attributing agency to Findlinge, these authors seek to understand them as an archive of a continuous geological history that has relevance to modern life forms. Findlinge thereby become a means of exploring the contemporary scientific explanations for the earth's geological history.

As a geological metaphor, the word Findling appears only from the second half of the nineteenth century on. ${ }^{7}$ In their dictionary, Ja-

\footnotetext{
${ }^{6}$ Robert Jameson, Cuvier's English translator, added notes to the English edition to explain that the most recent catastrophe could be identified as the Biblical Flood, and the British geologist William Buckland purported to follow Cuvier. In fact, he actually amended the theory and claimed that the flood had covered the entire globe (Robertson 350).

${ }^{7}$ This is according to the Etymologischer Duden (1989) and Friedrich Kluge's Etymologisches Wörterbuch der Deutschen Sprache (1995), as noted by Schellenberger-Diederich (208). Incidentally, SchellenbergerDiederich explains that for this reason, Heinrich von Kleist did not refer to
} 
cob and Wilhelm Grimm give Droste-Hülshoff credit for lending the term its geological meaning in "Die Mergelgrube," but Hans Lüschen has shown that the term had been used in a publication three years previously by the biologist Lorenz Oken (218). Considering that Droste-Hülshoff met Oken in 1836 and again in 1844, he or his works may well have been a source for the term (SchellenbergerDiederich 210). ${ }^{8}$ For Oken, Findlinge were natural - rather than divine - occurrences that needed explanation. How could a rock have moved across the earth? The larger the rock, the more pressing the question. Otfried Wagenbreth makes clear just how urgent this question would have been for people in northern Germany who saw so many of these large blocks apparently strewn across the fields. Because they were removed in the nineteenth and twentieth centuries, it is difficult to imagine today how imposing and puzzling these rocks would have been (Wagenbreth 118; qtd. in Schellenberger-Diederich 206-207). Another term used by Oken is Irrblöcke ("wandered stones"), which gives the impression of personified rocks wandering and losing their way (Schellenberger-Diederich 210). As Schellenberger-Diederich points out, even the recent Lexikon der Geowissenschaften (2000) continues to refer to the formulation Irrblock (211), though it is distanced from the surrounding scientific explanation by quotation marks and no longer a technical term. ${ }^{9}$ It nonetheless shares the quality of personification with the term Findling:

Die Gesteinart oder die Mineralzusammensetzung von Erratika steht im Ursprungsgebiet der Gletscher an, ist aber am Fundort des „Irrblockes" sonst nicht zu finden. Große Erratika werden als Findlinge bezeichnet. In der glazialgeomorphologischen Forschung [ . . . sind sie doch oft

geology in his 1810 novella Der Findling (Schellenberger-Diederich 209). She disagrees with Irmgard Wagner, who interprets Kleist's Findling as a geological signifier, which Wagner claims would place the novella "in the epistemological context of its time" (281).

${ }^{8}$ The publication in question is Lorenz Oken's Allgemeine Naturgeschichte für alle Stände (637).

${ }_{9}^{9}$ As seen in the cited entry, Findling, however, is still recognized as a scientific term by this lexicon, although its entry in the lexicon simply contains a reference to the "Erratika" entry. 
der einzige Hinweis auf die ehemalige Existenz von Gletschern. ("Erratika") ${ }^{10}$

These erratic rocks are now known to have been transported by glaciers, as indicated in the above lexicon entry. But in his 1839 publication, Oken wondered how stones that matched mountains in Scandinavia had ended up in the fields of northern Germany. The phenomenon was noteworthy not only due to the rocks being out of place, but also with regard to their composition. Granite, the oldest known mineral formation, had ended up on top of younger mineral layers such as schist and limestone (Wagner 285). Oken was not the first scientist to wonder about this issue. Ever since Peter Simon Pallas first suggested in 1771 the possibility that the rocks had been carried by water, a number of theories and counter-theories had been put forth by geologists, scientists, and explorers, including Johann Karl Wilhelm Voigt (Wagenbreth 118). As a mineralogist for the Grand Duchy of Saxe-Weimar-Eisenach, Voigt carried out research for Goethe, minister of mining at the time, and likely inspired many of the geological considerations in Goethe's literary works. In the early 1780s, Goethe and Voigt explored the Findlinge in the Thuringian Forest together and Voigt published his theory in "Drey Briefe über Gebirgslehre" ("Three Letters on Mountain Doctrine") in 1786 (Krüger 116). It was a topic that would occupy Goethe for years to come, and at least until 1816, Goethe held that Findlinge were ancient stone debris from the south (116). But the glacial theory was revived by several scientists in the 1820 s (117-18), and Goethe recalled, 40 years after his excursions with Voigt, that they had often discussed "die wunderbaren Erscheinungen der Blöcke, über Thüringen und über die ganze nördliche Welt ausgebreitet" $" 11$ and specu-

\footnotetext{
10 "The type of stone or the mineral composition of erratics is present at the original location of the glaciers but is not otherwise found at the site of the "wandered stone." Large erratics are designated as Findlinge. In glacialgeomorphological research [...] they are often the only hint at the former existence of glaciers." (Unless otherwise indicated, all translations of German texts are my own.)

11 "the splendid manifestation of the boulders, spread across Thuringia and across the whole northern world".
} 
lated about whether great blocks of ice had drifted southwards and deposited these Findlinge (qtd. in Krüger 116).

Like these geologists and explorers before him, Oken suggested the possibility of massive floods or glaciers. Droste-Hülshoff's poem "Die zorn'ge Welle hat sie hergescheucht"12 (17) emphasizes the former; the latter turned out to be the correct explanation (Schellenberger-Diederich 212). ${ }^{13}$ One of the mysteries that Droste-Hülshoff addresses in "Die Mergelgrube" is the discovery of a fossilized sea creature on dry land: "Ha, auf der Schieferplatte hier Medusen - / Noch schienen ihre Strahlen sie zu zücken" "(57-58). These lines in the poem could be based on a fossil of a jellyfish or starfish DrosteHülshoff heard about or perhaps discovered herself. Following Cuvier, she hypothesizes that a catastrophic event flung them there: "Als sie geschleudert von des Meeres Busen, / Und das Gebirge sank, sie zu zerdrücken" (59-60). ${ }^{15}$ At the time, the existence of fossilized sea creatures high above sea level and far from the shore must have seemed like evidence for a flood of ocean waters over the European continent rather than glaciers' slow transportation of Findlinge containing fossils from the Baltic Sea region. Droste-Hülshoff's take on this flood as catastrophic stands in opposition to adherents of the diluvial theory of Neptunism, such as Goethe, who believed a universal ocean had gradually receded (Robertson 350). Her engagement with contemporary geological theories in her poetry also stands out in opposition to the withdrawn domestic life that she is sometimes portrayed as having led (Joeres 53-54).

Although Droste-Hülshoff is often seen as a Heimat poet, and it is true that a great deal of her work provides insight into the inhabitants and landscape of Westphalia, she does not simply celebrate or ro-

\footnotetext{
12 "The angry wave shooed them to here".

${ }^{13}$ Robertson argues that Droste-Hülshoff does distance herself from the theory of a global flood here by reporting on it with humor (348). She describes Leviathan swimming above Mount Sinai and mountains melting like sugar candy (lines 18-21).

14 "Ha, on the slate slab here jellyfish - / Still they seemed to move their tentacles".

15 "When they were flung from the ocean's bosom, / And the mountains sank, to crush them."
} 
manticize an ideal of home and belonging. Rather, the many uncanny elements in her works show that she challenged the idea of Heimat as a peaceful grounding force or an ideal of an individual being in harmony with the landscape. Not only does she undermine the idea of being rooted in one's home soil - this is a problem, for example, for the main figures in her prose works Die Judenbuche (The Jews' Beech Tree) and Bei uns zu Lande auf dem Lande (Country Life in Our Country) - but she also connects this scepticism with broader questions about the geological history of the earth and humans' place in it, as seen in the poems "Die Mergelgrube" and "Der Hünenstein" ("The Giants' Tombstone").

Her curiosity about this topic is noteworthy since before Darwin published his theory of evolution, most people did not think of the earth or human and animal life as having a history longer than the one described in the Bible. Even Droste-Hülshoff relied on a biblical timeline for the history of the earth, as seen in an 1839 letter to Wilhelm Junkmann, in which she reports finding fossilized plants and scallops and wonders about the possibility of finding a fourthousand-year-old human preserved in stone (qtd. in Robertson 34647). ${ }^{16}$ And yet scientific evidence was beginning to emerge in Droste-Hülshoff's lifetime that contradicted this timeline and challenged some aspects of faith. In her letter, Droste-Hülshoff continues to wonder why human fossils are never found, and speculates about a pre-biblical period in which humans were not present, thus revealing her awareness of the tension between the evidence provided by fossil remains and the biblical narrative (Robertson 346).

The tension and doubt that mixed with Droste-Hülshoff's religiosity have been recognized in regard to the poem cycle "Das geistliche Jahr" ("The Spiritual Year"), especially "Am zweiten Weihnachtstage" ("On the Second Day of Christmas), written in 1840 (Robertson 345). Ritchie Robertson points to "Die Mergelgrube" as a further example of Droste-Hülshoff's reflection on the contradictions

\footnotetext{
${ }^{16}$ That she would limit the potential age of a human fossil to only four thousand years is what shows her reliance on a biblical timeline. In other instances, as pointed out above and also below, the poem distances itself from the Biblical accounts.
} 
between scientific knowledge and Genesis (352-54). In this poem, the poetic subject examines stones and minerals of various origins that suggest the earth is a dynamic rather than a static entity. The presence of fossils of living forms that are either extinct or from the distant ocean is an indication that the earth in its present form did not emerge fully formed as a divine creation. The result is both disorientation as well as identification with these geological remnants, as the lyrical I - who is revealed as male towards the end of the poem senses that he himself has become a fossil and later in the poem, a Findling.

Early in "Die Mergelgrube," the lyrical I has not yet emerged as a figure in his own right; the first-person reference to an "Ich" does not appear until line 34 in the second stanza. Instead, the poem begins by addressing a "Du":

Stoß deinen Scheit drei Spannen in den Sand,

Gesteine siehst du aus dem Schnitte ragen,

Blau, gelb, zinnoberroth, als ob zur Gant

Natur die Trödelbude aufgeschlagen. $(1-4)^{17}$

The address of a "Du" may represent the poetic subject speaking to himself, but it also immediately draws in the reader of this poem, as if asking for an active participant in the excavation of Findlinge. Through this uncertainty, the opening lines highlight the stones rather than the poetic subject, which is appropriate considering the poetic subject's confession to feeling alienated, later in the poem. In this way, the poem can be seen as preparing from the outset to accord agency to the geological processes and materials of the earth rather than to a human subject. Yet, the lyrical I's subsequent loss of stable footing also correlates with the homelessness of these rocks. In the beginning, the poem emphasizes the colour variations of the stones that are compared to a junk booth ("Trödelbude"). Nature auctions its stones in this shop. The line "Nur wenige hat dieser

17 "Thrust your stick three spans into the sand, / You see rocks protruding from the cut, / Blue, yellow, vermilion-red, as if for an auction / Nature opened the junk booth." 
Grund gezeugt" $(15)^{18}$ reveals that the stones are foreign to the land where they are, perhaps as a result of violence, since the rocks are described as having been washed along by an angry wave (17). The poetic subject continues in this vein, describing these rocks as orphaned children, a connection already present in the term Findling:

Findlinge nennt man sie, weil von der Brust,

Der mütterlichen sie gerissen sind,

In fremde Wiege schlummernd unbewußt,

Die fremde Hand sie legt wie's Findelkind.

O welch' ein Waisenhaus ist diese Haide,

Die Mohren, Blaßgesicht, und rothe Haut

Gleichförmig hüllet mit dem braunen Kleide!

Wie endlos ihre Zellenreihn gebaut! (25-32) ${ }^{19}$

The use of the verb "gerissen" to describe being "ripped" from their mother's breast evokes a sense of lost nourishment, identity, homeland, and even language. The subsequent imagery that compares the stones to people of different races (30) evokes human migration and is suggestive of the violence enacted upon people who are forcibly uprooted and relocated. $^{20}$

18 "Only a few did this ground beget".

19 "Foundlings they are called, because from the motherly breast they are ripped / Into a foreign cradle slumbering unaware, / The foreign hand lays them like an orphan. / O what an orphanage is this heath / The Moors, pale face, and red skin / Uniformly enveloped with the brown dress! / How endless their cell rows are built!"

${ }^{20}$ The sentiment of lost homeland can also be nostalgia. In this and other works, such as Die Judenbuche (The Jew's Beech, 1842) Droste-Hülshoff uses imagery of the ground and soil to signify homeland and one's connectedness to it. This particular poem may be exploring the possibility that Heimat can only be expressed in terms of loss, or that the exploration of Heimat requires the presence of foreign influences or one's own alienation. These ideas inform the scholarship on Heimat. For example, Anton Kaes describes Heimat as the "utopian antithesis to alienation" (165). It is this concept of alienation that Droste-Hülshoff explores in her description of the rocks on the heath, which se represents in the guise of lost or abandoned children. 
While human alienation and the displacement of people are alluded to in this poem, this essay argues that the rocks in this poem - rather than serving primarily as metaphors - have their own significance as witnesses to natural historical, including geological processes, as well as to human history, the depth of which was only just beginning to be understood by scientists. As Iovino and Oppermann underscore, reading nonhuman matter only as a metaphor perpetuates an anthropocentric viewpoint that ignores the fact that humans are entangled in the agency of nonhuman matter (8). On the other hand, the helpfulness of metaphors lies in their ability to highlight existing and perceived similarities between human and nonhuman matter, and in this way, the strategy of anthropomorphizing matter can be viewed as productive in closing the gap between humans and nonhumans (8). The poetic subject in Droste-Hülshoff's poem both anthropomorphizes rocks and ascribes agency to them insofar as Findlinge are pulled out of soil that seems to be moving and making sounds of its own, as if containing a spark ("Funken") of life:

Mir über'm Haupt ein Rispeln und ein Schaffen,

Als scharre in der Asche man den Funken.

Findlinge zog ich Stück auf Stück hervor,

Und lauschte, lauschte mit berauschtem Ohr. $(41-44)^{21}$

A few lines later, the lyrical I becomes a Findling himself, and in doing so, discovers hidden potential. Not only does he, as a Findling, morph into an enduring source of life in a catastrophic environment, but also the identification with a piece of the earth allows him to imagine - and share - the "experience" of the earth in an episode of its natural history. ${ }^{22}$ Through the potential contained within the Findling,

21 "Above my head a rustling and moving, / As if someone were stirring the spark in the ash. / Foundlings I pulled out piece by piece, / and listened, listened with a befuddled ear".

${ }^{22}$ A proviso: Imagination is here required for the anthropomorphic transfer to take place, namely as the means to project an already imagined experience onto the earth. Experience may only thus, i.e., through such imagined projection, be shared between the " $\mathrm{I}$ " and the "earth". Findlinge can only 
emphasized once more through the comparison to a "spark," the poetic subject not only studies geological evidence but has the opportunity to experience the upheaval and energy of the earth in a nonhuman-centred way:

Ich selber schien ein Funken mir, der doch

Erzittert in der todten Asche noch,

Ein Findling im zerfall'nen Weltenbau.

Die Wolke theilte sich, der Wind ward lau;

Mein Haupt nicht wagt' ich aus dem Hohl zu stecken.

Um nicht zu schauen der Verödung Schrecken,

Wie Neues quoll und Altes sich zersetzte -

War ich der erste Mensch oder der letzte? $(49-56)^{23}$

The discovery of and identification with Findlinge sets into motion a scene of geological turmoil and desolation for the lyrical I. This is all revealed as a dream, thanks to which he ultimately emerges from the marl pit enriched: his imagined transformation yielded to key discoveries. The poetic subject has to become a Findling in order to fully harness the creativity that resides within the rocks, represented by the image of a spark that endures in the face of catastrophic events. The lyrical I's question, "Was I the first human or the last?" reveals that he quickly regains his consciousness of being human, but as the lyrical I moves in the poem's next stanza from an examination of rocks to the fossils contained within them, he continues to identify with the material world as "living":

Ha, auf der Schieferplatte hier Medusen -

Noch schienen ihre Strahlen sie zu zücken,

Als sie geschleudert von des Meeres Busen,

"experience" when the human "I" projects its animal sentience (at least) onto the rocks.

23 "I myself seemed to be a spark, that yet / trembled in the dead ash still, / A foundling in the crumbled world. / The cloud separated, the wind became mild; / My head I dared not stick out of the hollow. / So as not to see the horrors of devastation, / How the new emerged and the old disintegrated - / Was I the first human or the last?" 
Und das Gebirge sank, sie zu zerdrücken.

Es ist gewiß, die alte Welt ist hin,

Ich Petrefakt, ein Mammuthsknochen drinn! (57-62) ${ }^{24}$

The fact that the lyrical I's discussion of Findlinge includes not just minerals, but also fossils, provides further evidence that the poem is concerned with the life contained within these rocks and its relation to human life. The reference to the mammoth bone in particular stands out because the discovery of extinct species challenged existing understandings of the development of life on earth. On the basis of fossils, Cuvier had confirmed in 1796 that the mammoth was an extinct species that differed from any type of living elephant, raising the religiously troubling idea of extinction (Pittrof 156). In further contrast to prevalent religious beliefs, the juxtaposition in these lines suggests Droste-Hülshoff's resistance to the idea of humans as entirely disparate from other forms of life. As Darwin would show, precisely the opposite is the case, and this shared biological inheritance among all living creatures would later make evolutionary theory controversial. This move aligns her poem with a central tenet of material ecocriticism: "the emanating point of the narrative is no longer the human self, but the human-nonhuman complex of interrelated agencies" (Iovino and Oppermann 9). The living human and the now fossilized life forms are so intertwined in this part of the poem that they exchange places (and time) as the lyrical I examines the "Medusen" (jellyfish) ${ }^{25}$ fossils, imagining they are coming back to life, while he sinks into the ancient world and becomes a fossil.

"Die Mergelgrube" presents scenes of destruction and creation, and yet without a distinct destroyer or creator. It is striking that specific reference to God should be missing in a poem that implies creation by having the poetic subject ask if he is the first human (56) and

24 "Ha, on the slate slab here jellyfish - / Still they seemed to move their tentacles, / When they were flung from the ocean's bosom, / And the mountains sank, to crush them. / It is certain, the old world is gone, / I, fossil, a mammoth bone within it!"

${ }^{25}$ Lothar Jordan writes that the exact animal Droste-Hülshoff is describing cannot be identified for certain. See his thorough section on "Medusen" (148-50). 
also refers to the bible with a description of the Great Flood and the ark resting on Mount Ararat (20-22). Instead of depicting divine creation, the poem attributes the resurgence of life after the flood only to nature:

Als dann am Ararat die Arche stand,

Und, eine fremde, üppige Natur,

Ein neues Leben quoll aus neuen Stoffen. $-(22-24)^{26}$

New life here springs forth from matter itself, which can be understood as pursuing the notion of creativity "not alone as an exclusionary feature of human culture but as a property of life, and to an extent, of the material world itself" (Zapf 51). This recently formulated tenet of material ecocriticism, while not meant to imply magical transformation, does have something in common with the belief in spontaneous generation, which persisted until the mid-nineteenth century. The idea that small organisms could spontaneously emerge from non-living matter was not fully disproven until microscopic research was conducted by Louis Pasteur and John Tyndall in the second half of the nineteenth century (Strickberger 11). Until then, this mistaken belief undermined the notion of permanent continuity between organisms, as later established by Darwin (Strickberger 12). Droste-Hülshoff seems to be alluding to spontaneous generation in these lines, thereby attributing the regenerative potential of matter to nature itself rather than to a divine being. The poem also makes clear that the creativity inherent in these rocks involves the view of the longue durée, namely the transformation of once-living bodies into stone through the process of fossilization. ${ }^{27}$

26 "When then on Ararat the ark stood, / And, a foreign, lush nature, / A new life sprang from new material. -"

${ }^{27}$ Zapf notes that earth in particular is "almost an omnipresent metaphor and source of creativity" in many myths and cultural traditions (61). In "Die Mergelgrube," the earth is not only a source of metaphors and creativity but also a generative force in its own right. The earth fossilizes, generates itself as hybrid living matter. It also turns itself into the shrine of living matter's generative force precisely by "preserving" the "once-living" in the shape of fossils. 
Both nonhuman matter and humans are contingent on the regenerative power of the earth, but they are also subject to the dislocation and upheaval it causes. Findlinge have been strewn far from their origins; similarly, Droste-Hülshoff's poetic subject loses himself in a dream-like vision of a barren earth. Implicit in this particular human's feeling of alienation is the uncertainty about the human origins. The poem is replete with allusions to creation myths, but also acknowledges contemporary paleontological research, which suggested much longer geological epochs than previously believed and raised questions about the origins of life, especially human life (Robertson 345). As Susanne Silvia Navarre points out, DrosteHülshoff is writing "in the century of Darwin, a century in which pantheism must give way to more secular views" and the poem "Die Mergelgrube" captures "this uneasy shift from one script to another" (151). ${ }^{28}$ Thomas Pittrof argues similarly that Droste-Hülshoff avoids taking sides in this nineteenth-century conflict, instead writing a poem that arranges different theories alongside one another (167). While harmony remains out of reach within the poem, nature itself is the only instance that is able to offset the resulting feelings of alienation. The stanza that portrays a barren and desolate landscape and ends with the lyrical I asking if he is the first human or the last is directly followed by the appearance in the next stanza of fossilized sea creatures that still seem to be moving. Navarre observes here that "[i]f nature redeems the observing self through its beauty and spirit of renewal, it does so not because of an immanent divinity or a grand projection but because of its inherent qualities" $(150-51) .{ }^{29}$ This po-

\footnotetext{
${ }^{28}$ Similarly, Christin Grunert theorizes that the poem's line "die alte Welt ist hin" signifies Droste-Hülshoff's awareness that a new era was beginning, in which biblical accounts of time and geological processes could no longer be reconciled. The author also argues that the poetic subject's selfattribution as a fossil represents his fear of entering this new era despite his knowledge of scientific facts (139). While it may be a stretch to read this parallel into these particular lines, Droste-Hülshoff certainly portrays her lyrical subject on the brink of a new understanding of history and time.

${ }^{29}$ Jordan argues similarly that rather than displaying a religious optimism that celebrates nature as proof of God's goodness, Droste-Hülshoff's per-
} 
tential for renewal and transformation applies not only to the geological history of the earth, but also to humans as part of that natural world. The fact that the lyrical I describes becoming a Findling and then a fossil at precisely this moment highlights the interconnections between humans and the natural world. The final creative product is evinced by the poem itself, as Droste-Hülshoff takes the generative forces of nature as inspiration for this literary work. ${ }^{30}$

Droste-Hülshoff's literary and scientific interests intermingle in her use of words that would not be considered traditionally poetic. She names and describes stones and minerals - Gneus ("gneiss"), Spat ("spar"), Glimmer ("mica"), Porphir ("porphyry"), Feuerstein ("flint"), Karneol ("carnelian"); the proper name of a natural history author - Bertuch; ${ }^{31}$ and technical terms related to geological excavation - Gerölle ("loose rocks"), Gebröckel ("crumbled stone"), Schieferplatte ("slate slab"), Petrefakt ("fossil"), Grand ("gravel"). ${ }^{32}$ There are no direct references to evolution here, though Droste-Hülshoff may have been aware of theories that were circulating at the time when she wrote this poem. Darwin's correspondence between 1838 and 1844 shows that this was the period when he developed the core ideas of the theory of natural selection, although the Origin of Species was not published until 1859 (Jordan 143). She was certainly

spective reveals nature as fascinating because it is threatening and uncanny (Jordan 138).

${ }^{30}$ This interpretation of the poetry itself as an object is aligned with Helfer's assessment of Droste-Hülshoff's poetics: "language functions not as the creative effusion of the poetic subject that produces the poetic subject, but as an object in its own right: Poesie becomes an object, the object." (284, emphasis in original)

${ }^{31}$ At the end of the poem, the lyrical I discovers that the shepherd is reading a book: "»Bertuchs Naturgeschichte«; les't ihr das?" (Line 112) This is probably a reference to a work entitled Tafeln der allgemeinen Naturgeschichte nach ihren drey Reichen (1806) by Friedrich Justin Bertuch, a central figure in Weimar during the Age of Goethe who was probably best known for his picture encyclopedia on natural history, Bilderbuch für Kinder (Atkinson 168). Droste-Hülshoff's family owned this encyclopedia along with the accompanying 24-volume commentary written at Bertuch's request by the scientist C. Ph. Funke. (Nettesheim 16-17)

${ }^{32}$ Droste-Hülshoff's use of most of these terms is noted by Jordan. (137) 
aware of Cuvier's theory of catastrophism from Bertuch's books on natural history and through her brother-in-law, Joseph von Lassberg, and his contacts, including Lorenz Oken (Robertson 346). In fact, certain lines in Droste-Hülshoff's poem appear to agree with Cuvier's catastrophism theory: "Ein neues Leben quoll aus neuen Stoffen" $(24)^{33}$ and "Wie Neues quoll und Altes sich zersetzte - / War ich der erste Mensch oder der letzte?" (55-56). ${ }^{34}$ Cuvier's theory, in contrast to Jean-Baptiste de Lamarck's uniformitarian concept of gradual, continuous change, proposed that there were sudden upheavals due to natural catastrophes, and each geological age was discontinuous with the previous one (Strickberger 14), which would explain the references to new life in Droste-Hülshoff's poem. While Cuvier's catastrophist position was ultimately disproven by an understanding of the earth as perpetually dynamic due to processes that could be explained rationally, Cuvier did not dispute that the earth was very old and that fossil evidence proved this (Strickberger 17). ${ }^{35}$

Towards the end of "Die Mergelgrube," the lyrical I, who has revealed at least some adherence to Cuvier's theory, comes into conflict with the shepherd, who espouses a strictly biblical understanding of the past. The shepherd, who is described as indistinguishable from his sheep, whistles "Ave Maria" and confronts the lyrical I's scientific explorations with his biblically-oriented perspective:

Im Moose lag ein Buch; ich hob es auf -

»Bertuchs Naturgeschichte«; les't ihr das? -

Da zog ein Lächeln seine Lippen auf:

Der lügt mal, Herr! doch das ist just der Spaß!

Von Schlangen, Bären, die in Stein verwandelt,

Als, wie Genesis sagt, die Schleusen offen;

Wär's nicht zur Kurzweil, wär es schlecht gehandelt:

Man weiß ja doch, daß alles Vieh versoffen.

\footnotetext{
33 "A new life sprang from new material".

34 "How the new emerged and the old disintegrated - / Was I the first human or the last?"

${ }^{35}$ Robertson likewise explains how Cuvier used fossils, particularly their discovery in layers, as evidence for his theory of a series of violent upheavals of the earth. (349)
} 
Ich reichte ihm die Schieferplatte: »schau,

Das war ein Tier.« Da zwinkert er die Brau,

Und hat mir lange pfiffig nachgelacht -

$\mathrm{Daß}$ ich verrückt sey, hätt' er nicht gedacht! - ${ }^{36}$

In emerging from his geological exploration and reverie, the lyrical I comes across an odd but appropriate juxtaposition considering the topics he has been musing about: Bertuch's book on natural history as an example of a contemporary scientific perspective, and a shepherd who dismisses it as a series of amusing lies. The lyrical I attempts to show the shepherd a piece of evidence by handing over the fossil, but the shepherd only laughs. The story from Genesis about the Great Flood, which had been part of the poetic subject's vision about the displacing of the Findlinge in the poem's first stanza, is now a source of tension. The very existence of fossils is questioned by the shepherd, while the lyrical I, in turn, implicitly questions the legitimacy of the Genesis story. Pittrof points out that the shepherd simply does not understand what a fossil is, imagining it to be a cause of death rather than a long physical process, since he contradicts the idea by insisting that all of the animals drowned (Pittroff 159).

Although the shepherd is not convinced by the fossil as evidence, this exchange reminds us of the poetic creativity the ground has inspired. The lyrical subject awakens from his reverie and steps out of the marl pit, handing over not only the material result of the excavation, i.e., the fossil, but, indirectly, the poem itself, which functions as an analogous creative product. The fact that the lyrical I is not prepared to subscribe to the shepherd's religious viewpoint and instead clings to a fossil as a source of knowledge reveals Droste-

\footnotetext{
${ }^{36}$ In the moss lay a book; I picked it up - / »Bertuch's Natural History «; are you reading that? - /At that a smile crossed his lips: / He lies, sir! But that's the fun of it! / About snakes, bears, transformed into stone, / When, as Genesis says, the locks were open; / were it not for amusement, it would be poorly done: / Everyone knows that all the animals drowned. / I handed him the slate slab: »look / That was an animal.« At that he raised his eyebrows / And long laughed after me blithely - / That I was crazy, that he wouldn't have thought! -"
} 
Hülshoff's dissatisfaction with a purely biblical explanation of the earth's history. Instead, the poem's own genealogy - emerging from the depths of a subject who immerses herself (Droste-Hülshoff) in the study of nature including human nature - is made to correspond to nature's own generation and incorporation of the creativity of life, of natura naturans.

In the final part of "Die Mergelgrube," the lyrical I is addressed as "Herr" (115) by the shepherd. This is when it is revealed, perhaps surprisingly, that the lyrical subject is male. This happens at a moment when opposing religious and geological positions begin to look difficult to reconcile. The lyrical I, though he espouses scientific beliefs at the end of the poem, refers to the Findlinge in the second stanza as having been carried by the biblical flood's angry wave (17) and describes the ark landing on Mount Ararat (22). By the poem's conclusion, however, not only has he become more aware of the earth's instability through his scientific explorations - "Findlinge zog ich Stück auf Stück hervor" (43) ${ }^{37}$ - but he has gone through an experience of losing his own identity: "Ich selber schien ein Funken mir, der doch / Erzittert in der todten Asche noch, / Ein Findling im zerfall'nen Weltenbau" (49-51). ${ }^{38}$ By revealing the lyrical I's gender only at the end, Droste-Hülshoff indicates that gender is just one aspect of identity; moreover, it is a specifically human aspect, which only acquires importance in the context of social interaction. Until this point in the poem, the lyrical I has been solitary and his attempts at self-definition appear to lead to alienation or petrifaction. But as Helfer points out with regard to a number of other poems by DrosteHülshoff, she generally does not portray an estranged subject who is entirely alienated and searching for itself, but rather an intentional decentring and self-reflexive staging of the self as one object among many (284). "Die Mergelgrube," for example, begins not with the lyrical I, but with second-person address: "Stoß deinen Scheit drei Spannen in den Sand" (1). ${ }^{39}$ The lyrical I appears to be speaking

37 "Foundlings I pulled out piece by piece".

38 "I myself seemed to be a spark, that yet / trembled in the dead ash still, / A foundling in the crumbled world."

39 "Thrust your stick three spans into the sand". 
from a distance to himself, not unlike the address of the self as object in the poem "Das Spiegelbild," for instance (Helfer 280). Although the poetic subject in "Die Mergelgrube" begins with a self-directed command to exert agency by digging into the soil, human agency soon disappears as the lyrical I describes being transformed into a Findling, then a fossil, then a mummy. Human agency is replaced by the agency of the natural world in the depiction of geological transformations. This part of the poem makes clear that humans are irrelevant to the ancient developments of the earth, meaning that gender or any other expression of human identity would be extraneous. The explanation of these natural processes through science, however, does require human agency.

The address of the lyrical subject as "Herr" only toward the end of both this poem and the poem "Der Hünenstein" - another poem in which the lyrical subject gets lost in a daydream describing the immense power of nature as experienced through rocks - signals Droste-Hülshoff's attentiveness to the relevance of gender with regard to the kinds of exploratory activities undertaken by these poetic subjects. Beyond her studies and correspondence, Droste-Hülshoff took a hands-on approach to her interest in geology and actively dug for fossils to add to her collection (Robertson 346). Yet she must have experienced the ways in which contemporary gender roles determined the acceptability of her pursuits. A well-educated woman engaging in botanical or mineralogical excursions in her leisure time would not have been seen as challenging gender norms (Joeres 53). And gender could be reason enough for a woman's study to go unacknowledged, to be marginalized. Although women were included as part of the broader educated public, there was widespread sentiment that Wissenschaft ("science") was a realm that belonged to men (Phillips 156). Traditional notions of femininity have continued to determine how Droste-Hülshoff's biography and work are presented; most scholars emphasize that she was remarkably well informed on scientific topics for a woman of her time. ${ }^{40}$ Her standing as a poet has long been attributed an "exemplary feminine status" and her work has often been unproblematically studied in terms of

${ }^{40}$ See, for example, Grunert 138. 
gendered characteristics (Joeres 54, 62). Her inclusion in the German literary canon has even sometimes been justified with reference to the "maleness" of her writing (51-63). ${ }^{41}$ In "Die Mergelgrube," gender is introduced, notably, only when the poetic subject tries to reconcile his findings with the outside world. This may result from Droste-Hülshoff's critical awareness that a male scientist, or even amateur geologist, would be more believable than a woman in either role. In Droste-Hülshoff's world, men not only had greater access to the scientific community, but were also perceived to have a stronger connection to the landscape through their land ownership. Her poem brings to the fore the hidden agency of the material world; it also offers an unspoken observation of the agency denied to women. ${ }^{42}$

Many of the essays in Iovino and Oppermann's Material Ecocriticism volume seek to offset the ways in which humans establish agency as solely a unique prerogative of their species failing to see that nonhuman processes and substances have agency too. ${ }^{43}$ Iovino and Oppermann endorse a "different ethical stance" able to take into account humankind's obligations to the world, including the nonhuman (Oppermann 35). Less explicitly stated, though often implicitly acknowledged in these calls for a "radical rethinking of human and nonhuman relations" and "rewriting our own narratives and reinterpreting the world itself" (Oppermann 35), is the importance of hearing the narratives of historically marginalized human voices. These voices belong to people, as Simon C. Estok points out, who have long been denied agency (Estok 133). Literature can perhaps offer some counterbalance, as Zapf rightly acknowledges: "literature, especially since the romantic period, has provided a discursive space

\footnotetext{
${ }^{41}$ Levin Schücking, Droste-Hülshoff's friend and biographer, described the "masculine strength" of her writing and Droste-Hülshoff scholars have long reinforced this attitude. (Nollendorfs 325)

${ }^{42}$ Feminist scholarship on Droste-Hülshoff has examined her critical eye for issues of gender identity and representation. See, for example, Cora Lee Nollendorf's study on Margreth in Die Judenbuche and Ruth-Ellen B. Joeres's examination of Droste-Hülshoff's reflections on gender and selfrepresentation in her letters. (64-77)

${ }^{43}$ Sullivan refers to Jane Bennett's Vibrant Matter (2010) in making this point. (91)
} 
for articulating those dimensions of human life that were marginalized, neglected, or repressed in dominant discourses and forms of civilizational organization" (57). Droste-Hülshoff, as a female writer educated in botany and geology, raises questions with "Die Mergelgrube" not only about the material agency of the many geological features of the earth, but also about the agency of women in this context. The two are imbricated: nature and women (as nature) both with unequal status and diminished agency in comparison to "man" as representative of "Mankind" - have thus been conflated for centuries.

Like Droste-Hülshoff, Goethe was also interested in geology and mineralogy and likewise reflected on different theories about the earth in his literary works. Wilhelm Meisters Wanderjahre oder die Entsagenden (1829) begins with Wilhelm going to his father with a rock in his hand and asking what kind of stone it is. Later, Wilhelm witnesses a heated debate at a mountain festival between representatives of two theories about the shaping of the earth, Volcanism and Neptunism. ${ }^{44}$ As different opinions and explanations emerge, a few characters contend that there are some conditions of the earth that will never be explained, and refer as an example to "größere und kleinere Felsmassen, welche zerstreut in vielen Landen umherliegend gefunden und sogar noch in unsern Tagen als von oben herabstürzend aufgelesen werden" (Goethe, Wilhelm 261). ${ }^{45}$ These Findlinge, an impossible riddle, are seen as paradigmatic for the as yet inexplicable features of the earth, and the scattered blocks of granite in northern Germany are also the topic of a conversation between unnamed speakers that Goethe dictated as part of his Conversations with Eckermann in 1829 (Groves 31). Similarly, a debate emerges in the "Classical Walpurgis Night" of Faust II, this time between two ancient Greek philosophers: Anaxagoras, who celebrates volcanic, dramatic forces that shift land and raise mountains

${ }^{44}$ See Timothy J. Attanucci's discussion of how Goethe engages these theories. (121-23)

45 "larger and smaller rock masses, which are found scattered around in many lands and even still in our day are picked up when crashing down from above". 
(Volcanism), and Thales, who hails the creative element of water and argues that changes happen over time (Neptunism) (Goethe, Faust II lines 7852-7951). ${ }^{46}$ Their debate in this scene is inspired by an earthquake, an event from which the philosophers hope to glean knowledge about the processes behind the earth's formation (750049). According to Anaxagoras, the emergence of life forms is closely tied up with this phenomenon: "Schnell quilt der Berg von Myrmidonen, / Die Felsenspalten zu bewohnen; / Pygmäen, Imsen, Däumerlinge, / Und andre tätig kleine Dinge" (7873-76). ${ }^{47}$ Here Anaxagoras hypothesizes connections between shifting earth and the appearance of intelligent - if mythical - life, and associates the former with the immense productivity of the latter. On the one hand, Goethe refers here to old myths about creatures living inside rocks and mountains, an idea associated with Findlinge as well. The depiction gives the rocks the kind of agency that is separate from, and yet implicitly connected with human life. But on the other hand, Anaxagoras seems to be on the losing side of the debate with the more rational Thales, giving the reader the impression that such sudden changes are merely fantastical and scientifically unsupported. Anaxagoras, much like the lyrical I in "Die Mergelgrube," imagines the moon crashing into the earth in a scene of destruction: "Auf einmal reißts und blitzt und funkelt! / Welch ein Geprassel! Welch ein Zischen! / Ein Donnern, Windgetüm dazwischen!" (7925-27). ${ }^{48}$ But Thales reveals that this scene is in Anaxagoras's imagination, thereby lending credibility to the theory of Neptunism, while not discounting the scientifically relevant idea that intelligent life already existed alongside pre-biblical periods in the earth's geological history. This scene, like Droste-Hülshoff's poem, thereby shifts from a spectacle to a sober assessment of the surrounding world.

\footnotetext{
${ }^{46}$ See Kate Rigby's discussion of this debate in Faust II. (86)

47 "With Myrmidons the mountain teems, / Who occupy all chinks and seams, / With pygmies, emmets, gnomes, Tom Thumbs, / And their minute but active chums". (Trans. Arndt)

48 "Now rent with lightning flash and spark! / What rushing hiss! what rattling spatter! / Now thunders, monstrous stormwinds scatter! -" (Trans. Arndt)
} 
In Faust II as in "Die Mergelgrube," the earth's instability is at once inspiring and alarming. The characters portrayed by Goethe ponder and debate the history of the earth as they experience geological turmoil. One productive result is intellectual exchange, which occurs both between the fictional characters and presumably beyond the text, insofar as the literary product itself engages with contemporary debates. But another result is the portrayal of physical devastation and loss. The dialogue in Faust II includes an imagined meteorite crashing down to earth and flattening a mountain (7930-50), while similarly, the lyrical I in Droste-Hülshoff's poem slips into a daydreamed world of cataclysmic floods and geological shifts. His sense of alienation as he descends into the marl pit is reflected by a shift in imagery from visual to auditory impressions in the second stanza (33-56). Here Droste-Hülshoff uses the verbs "horchen" and "lauschen" (both meaning "to harken" or "to listen carefully") and nouns such as "Geharf" ("harp"), "Klänge" ("tones"), "Geisterhall" ("ghost echo"), "Zischen" ("hissing"), and "Rispeln" ("rustling”). In the following stanza, the lyrical I proceeds to describe himself as a "Petrefakt" ("fossil"), and then, as dust begins to cover him, he feels that he is a mummy $(62,66)$. Cowering in the marl pit, the lyrical I imagines he takes part in a geological upheaval, finding himself in the wrong - or an unknown - place and time, like the block of granite that a glacier has left behind (Schellenberger-Diederich 206). Likewise, Droste-Hülshoff's poem "Der Hünenstein" imagines falling into the past, a fall prompted by an encounter with a large gravestone through which the lyrical I is transported into an ancient, mythical world.

Goethe and Droste-Hülshoff both disorient their readers with their depictions of time travel and a desolate landscape. Yet, at the same time, these impressions of alienation and human irrelevance are offset by the inspiration these characters derive from the seismic shifts they eagerly experience, diving into them (and literally, into the marl pit) to discover how the earth itself can be an agent of change. They represent a way of thinking that is central to ecocriticism. To borrow Heather I. Sullivan's words, these fictional characters attempt to "overcome the spatial distinction between ourselves and the rest of the biosphere" and reject the idea that nature is something external to 
the human body that one interacts with only by choice (90). Sullivan gives other examples from Goethe's works, including Faust and Zur Farbenlehre (Theory of Colours), where seemingly solid humanistic and Promethean views are imbalanced by "a destabilizing of our bodily and cultural boundaries" that corresponds to what is now called "posthumanism" (82-83). Both Goethe's and DrosteHülshoff's characters' sensory experiences show this destabilization concretely in the works discussed here. Humans are not portrayed as having supremacy in the natural world but, rather, as uncertain players in far larger environmental processes. Sullivan also points to the "nonpastoral, nonharmonious, and most necessarily, ironic model in [Goethe's] literary works that keeps us alert to oversimplified idealizations of nature" (83). The same can be said of Droste-Hülshoff in regard to "Die Mergelgrube" and other poems in her "Heidebilder" cycle that problematize the idea of the earth and its soil as stable entities. For example, Droste-Hülshoff uses irony in "Die Mergelgrube" when the lyrical I is jolted back to a pastoral scene by a piece of lamb's wool at the conclusion of the poem. This irony keeps both Goethe's and Droste-Hülshoff's characters entangled with other material processes in ways that they do not understand and certainly cannot control. Rather than simplify or idealize nature, these authors return again and again to uncertain geological phenomena such as Findlinge in their works.

Findlinge, as seen in each of these literary selections by DrosteHülshoff and Goethe, are foreign to the land they inhabit and alienating to the people who encounter them. They are nonetheless a way of exploring the potential agency of the earth through the history contained within them and the various superstitions and scientific theories associated with them. For these authors, the geological history of the earth is both awe-inspiring and disconcerting. These rocks are in mysterious locations, having been adrift in a way that for humans might signify having gone off course or becoming lost but which is simply the result of those natural processes of which these "erratic" rocks were a part. As witnesses to what came before, they have moved great distances over long geological periods and hold natural historical traces in their very matter. The humans in each of the works discussed here attempt to discover not only the causes of geo- 
logical change but also whether they themselves have any agency in this apparent turmoil. They seem to discover that their lives are not entirely separate from these natural processes, even if they can only begin to guess the ways in which their existence is interconnected with non-human matter. Rocks in these works become a way of exploring what the earth might yield in the way of natural historical and geological information, including the origins of life on earth and the prehistoric topography of the planet. Literature allows us to see the ways in which the very material of the earth has triggered and sustained both mythological and scientific narratives and continues to provide the impetus for productive creative interactions between the human and non-human world.

\section{Works Cited}

Allaby, Michael. "Glacial Theory." A Dictionary of Geology and Earth Sciences. Oxford: Oxford UP, 2013. 249

Arndt, Walter, translator. Faust: A Tragedy. By Johann Wolfgang von Goethe. Ed. Cyrus Hamlin. 2nd ed. New York: Norton, 2001

Atkinson, Margaret E., ed. Annette Von Droste-Hülshoff: Poems. London: Oxford UP, 1964

Attanucci, Timothy J. "Stories from Earth: Adalbert Stifter and the Poetics of Earth History." Diss. Princeton U, 2012

Bächtold-Stäubli, Hanns, ed. Handwörterbuch des deutschen Aberglaubens. Berlin: de Gruyter, 1930

Brandt, Lindsey J. "Tangled up in Truths: German Literary Conceptions of Nature between Romantic Science and Objective Empiricism." Diss. U of North Carolina at Chapel Hill, 2015

Cohen, Jeffrey Jerome. Foreword. "Storied Matter." Material Ecocriticism. Ed. Serenella Iovino and Serpil Oppermann. Bloomington: Indiana UP, 2014. ix-xii

Droste-Hülshoff, Annette von. "Die Mergelgrube." Histo-rischkritische Ausgabe. Ed. Winfried Woesler and Winfried Theiss. Vol. 1.1. Tübingen: Max Niemeyer, 1985. 50-53 
"Erratika." Lexikon der Geowissenschaften. Heidelberg: Spektrum Akademischer Verlag, 2000

Estok, Simon C. "Painful Material Realities, Tragedy, Ecophobia." Material Ecocriticism. Ed. Serenella Iovino and Serpil Oppermann. Bloomington: Indiana UP, 2014. 130-40

Goethe, Johann Wolfgang von. Faust: Zweiter Teil. Hamburger Ausgabe in 14 Bdn. Ed. Erich Trunz. Vol. 3. München: Beck, 1996

---. Wilhelm Meisters Wanderjahre. Hamburger Ausgabe in 14 Bänden. Ed. Erich Trunz. Vol. 8. München: Beck, 1981

Grimm, Jacob and Wilhelm. "Findling." Deutsches Wörterbuch. 16 vols. Leipzig: Hirzel: 1854-1961. Web. 22 December 2016

http://www.woerterbuchnetz.de/DWB?lemma=findling

Groves, Jason Nathanial van Nostrand. "Erratic: Fictions of Movement in Goethe, Stifter, and Benjamin." Diss. Yale U, 2012

Grunert, Christin. "Conflict with the Perception of Time as Fertile Ground for Collective Insecurity: The Frightening Reality of Scientific Facts and Their Transformation in Literary Fiction." Fear and Fantasy in a Global World. Ed. Susana Araújo, et al. Leiden: Brill, 2015. 123-42

Hannover. Fachbereich Umwelt. "19. Verordnung über Naturdenkmäler in der Region Hannover (Neuregelungsverordnung)." Gemeinsames Amtsblatt für die Region Hannover und die Landeshauptstadt Hannover - Sonderausgabe. 4 October 2010. PDF files. 17 May 2016

www.hannover.de/Leben-in-der-Region-Hanno-ver/Verwaltungen-Kommunen/Bekanntmachungen Ausschreibungen/Gemeinsames- Amtsblatt-Sonderausgabe-Jahrgang 2010

Helfer, Martha B. “'Ein heimlich Ding': The Self as Object in Annette von Droste-Hülshoff." Goethe's Ghosts: Reading and the Persistence of Literature. Ed. Simon Richter and Richard Block. Rochester, NY: Camden House, 2013. 276-89

Hurni, L. "Geologische Objekte: Findlingsreservat Längholz bei Biel." Mitteilungen der Naturforschenden Gesellschaft in Bern 38 (1981): 53-64

Iovino, Serenella and Serpil Oppermann. Introduction. Material Ecocriticism. Ed. Iovino and Oppermann. Bloomington: Indiana UP, 2014. 1-17 
Joeres, Ruth-Ellen B. Respectability and Deviance: NineteenthCentury German Women Writers and the Ambiguity of Representation. Chicago: U of Chicago P, 1998

Jordan, Lothar. "Annette von Droste-Hülshoffs langes Gedicht Die Mergelgrube: Paläontologie und literarische Innovation." Von Schillers Räubern zu Shelleys Frankenstein: Wissenschaft und Literatur im Dialog um 1800. Ed. Dietrich von Engelhardt and Hans Wißkirchen. Stuttgart: Schattauer, 2006. 131-56

Kaes, Anton. From Hitler to Heimat: The Return of History as Film. Cambridge: Harvard UP, 1989

Krüger, Tobias. Discovering the Ice Ages: International Reception and Consequences for a Historical Understanding of Climate. Trans. Ann M. Hentschel. Leiden: Brill, 2013

Lüschen, Hans. Die Namen der Steine: Das Mineralreich im Spiegel der Sprache. 2nd ed. Thun: Ott, 1979. Print.

Mecklenburg-Vorpommern. Landesamt für Naturschutz, Umwelt und Geologie. "Findlinge." N.d. Web. 17 May 2016 http://www.lung.mv-regierung.de/insite/cms/umwelt/geologie/geotope/glazial/glazial_findling.htm

Navarre, Susanne Silvia. “'The Poetics of Everyday Life': The Sublime as an Aesthetic Force in the Lyric Poetry of Emily Dickinson and Annette von Droste-Hülshoff." Diss. Rutgers U, 2010

Nettesheim, Josefine. Die geistige Welt der Dichterin Annette Droste zu Hülshoff. Münster: Regensberg, 1967

Nollendorfs, Cora Lee. “ ‘... kein Zeugniß ablegen’: Woman’s Voice in Droste-Hülshoff's Judenbuche." The German Quarterly 67 (1994): 325-37

Nyhart, Lynn K. Modern Nature: The Rise of the Biological Perspective in Germany. Chicago: U of Chicago P, 2009

Oken, Lorenz. Allgemeine Naturgeschichte für alle Stände. Stuttgart: Hoffmann, 1839

Oppermann, Serpil. "From Ecological Postmodernism to Material Ecocriticism: Creative Materiality and Narrative Agency." Material Ecocriticism. Ed. Serenella Iovino and Serpil Oppermann. Bloomington: Indiana UP, 2014. 21-36

Phillips, Denise. Acolytes of Nature: Defining Natural Science in Germany, 1770-1850. Chicago: U of Chicago P, 2012 
Pittroff, Thomas. “'Bertuchs Naturgeschichte'; les't Ihr das? Annette von Droste-Hülshoff: 'Die Mergelgrube'. Naturge-schichte, Poesie, Apokalypse." Literaturwissenschaftliches Jahrbuch 42 (2001): 145-73

Rigby, Kate. Dancing with Disaster: Environmental Histories, Narratives, and Ethics for Perilous Times. Charlottesville: U of Virginia P, 2015

Robertson, Ritchie. "Faith and Fossils: Annette von DrosteHülshoff's poem 'Die Mergelgrube."' Das schwierige 19. Jahrhundert: Germanistische Tagung zum 65. Geburtstag von Eda Sagarra im August 1998. Ed. Jürgen Barkhoff, et al. Tübingen: Niemeyer, 2000. 345-54

Schaffer, Franz Xavier. Lehrbuch der Geologie, I. Teil: Allgemeine Geologie. Leipzig: Deuticke, 1922

Schellenberger-Diederich, Erika. Geopoetik: Studien zur Metapher des Gesteins in der Lyrik von Hölderlin bis Celan. Bielefeld: Aisthesis, 2006

Strickberger, Monroe W. Evolution. 3rd ed. Sudbury, Mass: Jones and Bartlett, 2000

Sullivan, Heather I. "The Ecology of Colors: Goethe's Materialist Optics and Ecological Posthumanism." Material Ecocriticism. Ed. Serenella Iovino and Serpil Oppermann. Bloomington: Indiana UP, 2014. 80-94

Wagenbreth, Otfried. Geschichte der Geologie in Deutschland. Berlin: Springer, 1999

Wagner, Irmgard. "Der Findling: Erratic Signifier in Kleist and Geology." The German Quarterly 64 (1991): 281-95

Wilke, Sabine. "Toward an Environmental Aesthetics: Depicting Nature in the Age of Goethe." Goethe's Ghosts: Reading and the Persistence of Literature. Ed. Simon Richter and Richard Block. Rochester, NY: Camden House, 2013. 262-75

Zapf, Hubert. "Creative Matter and Creative Mind: Cultural Ecology and Literary Creativity." Material Ecocriticism. Ed. Serenella Iovino and Serpil Oppermann. Bloomington: Indiana UP, 2014. 51-66

“Zeugen aus dem Norden.” Schichten und Schieben. Museum Lüneburg. Lüneburg, Germany. 12 June 2016. Exhibit 